\title{
The Use of Debates as an Approach to Deliver the Course Entitled "The Impact of US Policy on Integration Processes in Europe in the Post-Bipolar Era"
}

\author{
Alina Yu. Korniienko ${ }^{1}$ \\ ${ }^{1}$ Department of Modern and Contemporary History of Foreign Countries, Faculty of History, Taras Shevchenko \\ National University of Kyiv, Kyiv, Ukraine \\ Correspondence: Alina Yu. Korniienko, Department of Modern and Contemporary History of Foreign Countries, \\ Faculty of History, Taras Shevchenko National University of Kyiv, 60 Volodymyrska str., Kyiv, Ukraine, 01033.
}

\author{
Received: February 19, 2020 \\ Accepted: April 8, 2020 \\ Online Published: April 9, 2020 \\ doi:10.5430/ijhe.v9n2p321 \\ URL: https://doi.org/10.5430/ijhe.v9n2p321
}

\begin{abstract}
The purpose of this research was to identify how the use of a debate-based course delivery approach merged with a flipped classroom model influenced the students' academic outcomes and motivation in relation to their intelligence type and how the sampled students perceived the course delivery approach and certain debate-related activities. Sampled students' academic performance records, an evaluation survey to obtain students' feedback on both the course delivery approach and the effectiveness of the activities like 'Think-Pair-Share', 'Write-Pair-Share', 'Illogical story-telling', 'Treasure Hunt', case-study, 'One Minute Paper', 'Attitude/motivation test battery' as intelligence type-based diagnostics of learners' motivation, and a focus-group semi-structured interview were used as the instruments. SPSS 10.0.5 computer statistical package was used to process data. The use of debates to deliver the instructional content to the tertiary students can be considered a three-vector approach capable to bring a positive change to learning motivation, cognitive (intellectual) activity, self-esteem (self-efficacy) of a student and the overall quality of the vocational training system of the historians and lawyers-to-be. This study boosts the methodology of vocational training of the students majoring in humanities like History/Law in terms of fostering the $21^{\text {st }}$ century-competencies and it adds a different perspective to the theory on relation between the type of intelligence and skills. This approach fosters learner autonomy and positive perception of challenging educational activities. It was found that it was prerequisite for the success of the above approach that there was a well-trained debate moderator, and debate-procedure-aware and trained students. The further research is needed in purposeful introduction of NLP training into the above model and examination its impacts.
\end{abstract}

Keywords: debates, historians-to-be, tertiary education, flipped classroom

\section{Introduction}

The use of debates as an approach to deliver the instructional content has gained attention for being a learner's motivation enhancer, academic achievement booster, student engagement tool and brain capacity improvement instrument (Abernathy \& Forestal, 2019; Brown, 2015; Gooblar, 2016; Najafi, Motaghi, Nasrabadi \& Heshi, 2016). The history-related course-which is in the scope of this study, is primarily about the interpretation of facts and available knowledge, meaning that debating can, and has been resourceful for students majoring in humanities (History Teaching/Anthropology/PR/Political Science) in terms of mastering communication, analytical, searching information, and problem-solving skills (Anders, 2016; Yarema, 2002).

Though seeming and proven to be effective, debates are not suitable for every type of intelligence. They are suitable for the type which is characterised by the quick response, increased intellectual concentration, being stress-proof and logical because the flow of the debate is typically quite unpredictable (Doody \& Condon, 2012; Williams-Brown \& Wilson, 2016; Zare \& Othman, 2013). Furthermore, the debate-drive approach is effective when both students and instructors are sufficiently prepared for classroom learning which means that a flipped course design seems to be the best available learning mode option (University of Waterloo, n./d.). 


\subsection{Flipped Classroom and Debate-Based Training}

The literature review found six types of flipped classrooms that have been recommended by $96 \%$ of tertiary educators (Sagenmüller, 2020). It is reported that the flipped classrooms bring more benefit to the students than the traditional read/listen-memorise-and-re-tell approach. Those types were traditional (standard), debate(discussion)-oriented, demonstration-based, group-based, virtual and double-flipped (flipping the instructor) ones (Sagenmüller, 2020). Sagenmüller's (2020) and Panapto (2019) view of the suitability of the debate-oriented type for the subjects that required argumentation skills was in line with this research authors' perspective.

Although this literature review found an extensive body of the research revealing theoretical and methodological aspects of using debates in education and vocational training (Ang, Chew, Sum, Sengupta \& Sim, 2019; Kennedy, 2009; Omelicheva, 2006; Toner \& Woolley, 2016), there was a gap related to the relationship between the use of the debate and academic performance, students' satisfaction of the course delivery approach and some debate-related activities, and learners' motivation with regard to the participants' type of the intelligence.

\subsection{Research Questions}

The purpose of this research was to identify 1 ) how the use of a debate-based course delivery approach merged with a flipped classroom model to influence the students' academic outcomes and motivation in relation to their intelligence type and 2) what was the sampled students' attitude to of the course delivery approach and some debate-related activities.

\section{Materials and Methods}

This was a mixed-methods research (Schoonenboom \& Johnson, 2017). It used students' academic performance records, 'Attitude/motivation test battery' to collect quantitative data. An evaluation survey to obtain students' feedback on both the course delivery approach, and the effectiveness of such activities as 'Think-Pair-Share', 'Write-Pair-Share', 'Illogical story-telling', 'Treasure Hunt', case-study and 'One Minute Paper' and a questionnaire for a focus-group semi-structured interview were used to collect qualitative data. The variables for this study were students' academic performance, students' satisfaction with the course delivery approach and of some debate-related activities, and learners' motivation with regard to the type of intelligence.

\subsection{Research Design}

This study utilised a deductive-sequential research design with a quantitative component being a priority, and a qualitative one used as supplemental (Morgan, 2014). This research taken over the course of 2018-2019, was a flow of three stages: 1. a prior-treatment stage - examination of the concepts, empirical data, models, assumptions and best practices to specify the research gap, to work out the research questions and research design; 2. a treatment (experimental)-stage - the use of a debate-based course delivery approach merged with a flipped classroom model to influence the above variables (see Appendix 1 for the example of a lesson plan); 3. a post-treatment stage processing and interpreting the entry and outcome data collected (see it detailed in Fig 1. below). 


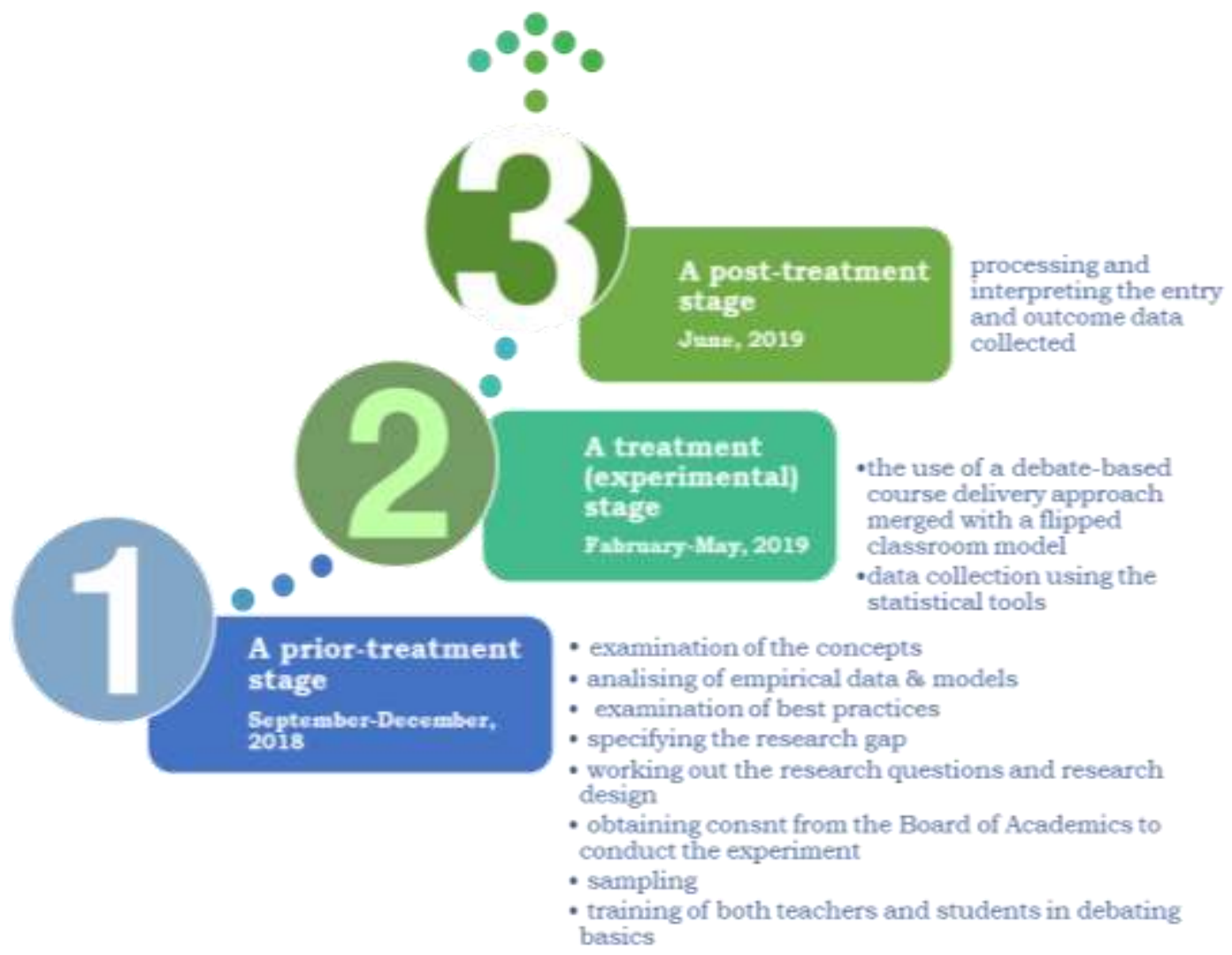

Figure 1. The flow of this research

At the prior treatment stage, both teachers and experimental group students were trained in debate procedure and techniques, the use of persuasive and functional language.

2.2 The Outline of the Elective Course Entitled "The Impact of US Policy on Integration Processes in Europe in the Post-Bipolar Era"

Course type: elective

Course duration: 112 hours

Assessment: European Credit Transfer System (ECTS).

The course objectives were to increase students' awareness of the specifics of foreign policy and status of the EU and US in international relations, the basic principles they both participate in the world politics; to explore the areas of the EU-US cooperation in world politics in the post-bipolar era.

The course outcomes were expected to be the students' improved ability and skills to monitor the dynamics of the main characteristics of the environment of international security and understanding of its impact on the national security of Ukraine; the improved analytical skills of collecting and analysing information, problem-solving, and making decisions on the world economic, environmental, demographic, migration processes, understanding the mechanisms of mutual influence of the EU-US environment, the EU-US economy, the EU-US politics.

\subsection{The Topics for the Debates}

1. Is the EU-US cooperation a blessing or a curse?

2. Is Ukraine going to reap benefits of long-term trade deals with the EU-US integration or just be an emerging consumer market to them?

3. Political roller coasters of international policies of the USA and EU: what lies ahead?

\subsection{Population \& Sampling}

Bachelor's degree students in their second year studying History and Law at National Pedagogical University were 
sampled for this study. As the course was elective, the research was advertised through the teachers, university newspaper, posters, releases, social media, website-as a non-traditional delivery approach-based that encouraged them to apply. The population sample of 57 applicants was then reduced to 36 people to form the experimental and control group (EG and CG) each involving 18 people. This number of people was confirmed to be optimal by our literature review findings (Doody and Condon (2012) - 25 students; Williams-Brown (2015) - 16 sampled leaners). Moreover, the sample size of 18 people was also sufficient for this study from the perspective of classroom management assuming that the affirmative and opposing teams usually involve three people each, and there should be the panel of three judges and the audience. Thus, there were 12 female and 6 male students in the EG, and 13 female and 5 male students in the CG.

The students sampled for EG and CG were tested for homogeneity using PsychTest (n./d.) and Attitude/motivation test battery (Gardner, 2004) (see the test results in Table 1 and Table 2). Students' academic performance records were analysed to select the ones with the scores varying between 70 to 89 ECTS (see Table 3).

Table 1. Mean values for the Multiple Intelligences \& Learning Style Test for EG \& CG

\begin{tabular}{lcccccccc}
\hline Group & VL & LM & VS & BK & M & IntraP & InterP & N \\
\hline EG, $n=18$ & 93 & 31 & 43 & 73 & 27 & 21 & 79 & 37 \\
CG, $n=18$ & 91 & 33 & 47 & 78 & 26 & 24 & 76 & 35
\end{tabular}

Note abbreviations: VL - Verbal/Linguistic; LM - Logical/Mathematical; VS - Visual/Spatial; BK Bodily/Kinesthetic; M - Musical; IntraP - Intrapersonal, InterP - Interpersonal; N - Naturalist.

Table 2. Results of the Attitude/motivation test battery, by students learning styles

\begin{tabular}{llccccc}
\hline Group & LS & Mean & $S D$ & $t$ value & $p$ value & Significance level \\
\hline EG, $n=18$ & \multirow{2}{*}{ Auditory } & 34.44 & 5.24 & \multirow{2}{*}{14.74} & .01 & $p \geq 0.05$ \\
CG, $n=18$ & & 35.13 & 6.09 & & & \\
EG, $n=18$ & Visual & 37.83 & 9.12 & & & \\
CG, $n=18$ & & 39.11 & 8.79 & 9.36 & .04 & $p \geq 0.05$ \\
EG, $n=18$ & \multirow{2}{*}{ Kinesthetic } & 43.22 & 7.21 & & & \\
CG, $n=18$ & & 46.01 & 7.10 & 8.99 & .03 & $p \geq 0.05$ \\
\hline
\end{tabular}

Note abbreviation: LS - Learning Style

Table 3. Academic performance scores distribution

\begin{tabular}{lcccc}
\hline Group & \multicolumn{3}{c}{ Scores } \\
& $70-74$ & $75-79$ & $80-84$ & $85-89$ \\
\hline EG, $n=18$ & $17 \%$ & $29 \%$ & $41 \%$ & $13 \%$ \\
CG, $n=18$ & $19 \%$ & $31 \%$ & $40 \%$ & $10 \%$ \\
\hline
\end{tabular}

It appears that the intelligence types of the above groups complied with both auditory and visual learning styles (Kowald, 2019) which meant that verbal/linguistic and interpersonal intelligence types were dominant in the students. It fitted the teaching approach used in the study as debating is mostly based on the teamwork, communication, problem-solving.

After the intelligence types were determined, the modified 19-question section of Attitude/motivation test was used to explore the level of students' motivation to study History and Law. The consolidated results are distributed by students learning styles. Cronbach's Alpha was 0.93 . Both sampled groups suited the experiment as their entry test results and academic performance were approximately the same. Additionally, 10 people for the EG were randomly sampled for the focus group interview.

\subsection{Data Collection and Processing Instruments}

The instruments were sampled students' academic performance records, an evaluation survey to obtain students' feedback on both the course delivery approach and the effectiveness of such activities as 'Think-Pair-Share', 'Write-Pair-Share', 'Illogical story-telling', 'Treasure Hunt', case-study, 'One Minute Paper', 'Attitude/motivation test battery' as intelligence type-based diagnostics of learners' motivation, and a questionnaire for a focus-group semi-structured interview. SPSS 10.0.5 computer statistical package was used to process data. 


\subsection{Evaluation Survey}

The evaluation survey was split up into two sections. First section comprised Questions 1 to 3, which were based on a 4-point Likert scale with 1 meaning 'poor', 2 - 'average', 3 - 'good', 4 - 'excellent'.

The second section included Questions 4 to 9 using a 5-point Likert scale with 1 meaning 'not at all helpful' 2 - 'not so helpful', 3 - 'somewhat helpful', 4 - 'very helpful' and 5 - 'extremely helpful'.

\section{Results}

To complete the experimental stage, the participating students' academic performance in both groups (EG and CG) was analysed, and Multiple Intelligences \& Learning Style Test and Attitude/motivation test battery were administered.

After the results were obtained, Cronbach's Alpha and McDonald's omega were used to analyze each dimension (students' academic performance, students' satisfaction of the course delivery approach and of some debate-related activities, and learners' motivation with regard to the type of the intelligence) individually. Confirmatory Factorial Analysis (CFA) was used to find the correlation amongst the dimensions.

Assuming that the values which were greater than .70 are considered satisfactory, the values which are higher than .80 are regarded good and those greater than .90 are excellent (George \& Mallery, 2006), the correlation amongst the dimensions was reliable and statistically significant.

The questionnaire and the interview were to increase the reliability of this study.

The below is the result of the survey intended to find out how the students felt about the course delivery approach and the effectiveness of some activities.

Question 1. Overall, how would you rate the course? The majority of the respondents (63\%) rated the course as 'good", $21 \%$ surveyed reported it was 'excellent', and $16 \%$ of people stated it was 'average'

Question 2. How would you evaluate the teacher's performance? $87 \%$ of the surveyed assessed the teacher's performance as 'excellent', and the rest of the group (13\%) reported it was 'good'.

Question 3. How would rate course format? The course format appeared 'excellent' for $11 \%$ of sampled students, it was 'good' for $59 \%$ of people and it was 'average' for the rest (30\%) of the respondents.

Question 4. How helpful was 'Think-Pair-Share' activity to your effectiveness as a debater? 7\% of the sampled students stated it was 'very helpful', $87 \%$ reported it was 'somewhat helpful', and $6 \%$ confessed it was 'not at all helpful'.

Question 5. How helpful was 'Write-Pair-Share' activity to your effectiveness as a debater? 3\% of the surveyed it was 'somewhat helpful' and $97 \%$ of the people chose 'not so helpful' option.

Question 6. How helpful was 'Illogical story-telling' activity to your effectiveness as a debater? $73 \%$ responded it was 'very helpful', $21 \%$ answered it was 'somewhat helpful', and $6 \%$ decided it was 'not so helpful'.

Question 7. How helpful was 'case-study' activity to your effectiveness as a debater? 9\% decided it was 'somewhat helpful' for them while $91 \%$ of the sampled students reported it was 'not so helpful'.

Question 8. How helpful was 'One Minute Paper' activity to your effectiveness as a debater? 37\% of the participants responded it was a 'very helpful' activity, $53 \%$ of the surveyed reported it was 'somewhat helpful', and $10 \%$ of the people claimed it was 'not so helpful' for them.

Question 9. How helpful was 'Treasure Hunt' activity to your effectiveness as a debater? $72 \%$ of the involved students found this activity 'very helpful', $23 \%$ of the surveyed reported they found it 'somewhat helpful', and $5 \%$ of people stated it was 'not so helpful'.

No person responded that any activity was 'not at all helpful' as well as 'extremely helpful'.

\subsection{Questionnaire to Conduct a Focus-Group Semi-Structured Interview}

Question 1. How would you evaluate your performance in the course? Why? 76\% of the interviewed confessed that they felt they underperformed at the start of the project because of lack of confidence (which they gained at the end), lack of appropriate communication skills, lack of leadership abilities, lack of desire to change the behaviour model they acquired later and lack of awareness of debating procedures, etc. $24 \%$ of the focus group respondents found their performance satisfactory or good.

Question 2. What would you do differently when you did the same course second time? Why? $96 \%$ said that would 
definitely do the course in a different way paying more attention to the out-of-class assignments, contributing more into discussions and team writing activities. $4 \%$ were hesitant to answer this question.

Question 3. Would you recommend the course to your group mates? Why? 61\% responded to this question positively with the reasoning that such a format is not for everyone, while $39 \%$ of people were negative to this question for the same reason - it is not for everybody.

Question 4. What would you suggest improving to make the course more helpful? 63\% suggested that the prior course training in debating could be prolonged. $12 \%$ suggested amending the programme curriculum in terms of the introduction of the additional courses to train students in using logical fallacies, functional language, persuasion techniques. $37 \%$ offered to set up a debate club.

\subsection{Limitations}

Though the results of the experiment showed improvements, the above might be challenged as a result of several limitations like the number of sampled students, their major and the length of the study. Furthermore, the course context, dominant intelligence type, the limited set of activities used as an engagement tool can be also challenged and seen as limitations.

\section{Discussions}

The use of debates as an approach to deliver the course entitled "The impact of US policy on integration processes in Europe in the post-bipolar era" showed dynamics in sampled students' knowledge, skills, and attitudes. The above experiment proved that the use of debates can be more efficient if both students and teachers received training if the type of intelligence was considered, and if the activities were selected to fit the students learning style. The EG students reported the rise of their confidence as public speakers due to experimenting with language, improvement of their leadership and analytical skills which are crucial for their future job. Throughout the experiment, the researchers observed the change in the students' behaviour patterns while they were developing as 'experts' in the field of EU-US cooperation.

This study also found the relation between the use of a debate-based course delivery approach merged with a flipped classroom model and dominant intelligent type and learning style in students. Furthermore, it appeared to be suggestive in terms of making a shift from a traditional lecture-seminar-based training to a student-driven learning mode.

The experimental outcomes addressed the purpose of this study and comply with findings of Winarti, Yuanita and Nur (2019) indicating the effectiveness of using intelligence-based instruction. It goes in line with Zare and Othman (2013) and Najafi et al. (2016) proving that classroom debate can be used as a systematic teaching/learning approach. The study findings coincide with the study conducted by Jones (2013) and Kensington-Miller, Novak and Evans (2016) to have proved that the flipped class mode increases effectiveness of using debates as delivery approach.

This research contributed to methods of vocational training of the students majoring in History and Law, in particular: methods to develop historical thinking skills and abilities (Culminas-Colis, Garcia \& Reyes, 2016; Ledman, 2015), psychological and pedagogical theory on the relation between the type of intelligence and skills (McGreal, 2013; Mikolajczak, 2010; Scholastic, 2005).

\section{Conclusions}

The use of debates to deliver the instructional content to the tertiary students can be considered a three-vector approach capable to bring a positive change to learning motivation, cognitive activity, the self-esteem of a student and the overall quality of the vocational training system of the historians and lawyers-to-be. This study boosts the methodology of vocational training of the students majoring in humanities areas such as History/Law in terms of fostering the $21^{\text {st }}$ century-competencies and adds a different perspective to the theory on the relation between the type of intelligence and skills. This approach fostered learner autonomy and positive perception of challenging educational activities. It was found that it was prerequisite for the success of the above approach that there was a well-trained debate moderator, and debate-procedure-aware and trained students. Further research is needed in the purposeful introduction of NLP training into the above model and examination of its impacts.

\section{References}

Abernathy, C., \& Forestal, J. (2019). The Use of Debates in Political Science Courses. Journal of Political Science Education. https://doi.org/10.1080/15512169.2019.1656082

Anders, G. (2016). All History Is Controversial; Here's How to Teach It. Forbs. Retrieved from 
https://www.forbes.com/sites/georgeanders/2016/06/02/all-history-is-controversial-heres-how-to-teach-it/\#5f52 0f1e7ade

Ang, R. X., Chew, Q. H., Sum, M. Y., Sengupta, S., \& Sim, K. (2019). Systematic review of the use of debates in health professions education - does it work? GMS journal for medical education, 36(4), Doc37. https://doi.org/10.3205/zma001245

Brown, Z. (2015). The use of in-class debates as a teaching strategy in increasing students' critical thinking and collaborative learning skills in Higher Education. Educational futures, 7(1), 39-55.

Culminas-Colis, M. V., Garcia, E. B., \& Reyes, W. M. (2016). Teaching Historical Thinking Skills Through "Reading Like a Historian" Method. The Normal Lights, 10(1), 56-77.

Doody, O., \& Condon, M. (2012). Increasing student involvement and learning through using debate as an assessment. Nurse education in practice, 12, 232-237. https://doi.org/10.1016/j.nepr.2012.03.002

Gardner, R. C. (2004). Attitude/motivation test battery: International AMTB research project. London, Canada: The University of Western Ontario.

George, D., \& Mallery, P. (2006). SPSS for Windows Step-by-Step: A Simple Guide and Reference, 14.0 update (7th ed.). Boston, MA: Allyn \& Bacon.

Gooblar, D. (2016). Skills First, and Let Content Follow. The Chronicle Vitae. Retrieved from https://chroniclevitae.com/news/1551-skills-first-and-let-content-follow

Jones, E. (2013). 'Flipped' classroom story sparks debate on teaching style. PBC News Hour. Retrieved from https://www.pbs.org/newshour/nation/facebook-users-flip-out-over-non-traditional-classroom

Kennedy, R. (2009). The power of in-class debates. Active Learning in Higher Education, 10, $225-236$. https://doi.org/10.1177/1469787409343186

Kensington-Miller, B., Novak, J. \& Evans, T. (2016). Just do it: flipped lecture, determinants and debate. International Journal of Mathematical Education in Science and Technology, 47(6), 853-862, https://doi.org/10.1080/0020739X.2015.1129075

Kowald, T. O. (2019). Understanding Multiple Intelligences and Learning Styles. Connections Academy. Retrieved from https://blog.connectionsacademy.com/learning-styles-multiple-intelligences/

Ledman, K. (2015). Navigating historical thinking in a vocational setting: teachers interpreting a history curriculum for students in vocational secondary education. Journal of Curriculum Studies, 47(1), 77-93. https://doi.org/10.1080/00220272.2014.984766

McGreal, S. A. (2013). The Illusory Theory of Multiple Intelligences. Psychology Today. Retrieved from https://www.psychologytoday.com/us/blog/unique-everybody-else/201311/the-illusory-theory-multiple-intellige nces

Mikolajczak, M. (2010). Going Beyond the Ability-Trait Debate: The Three-Level Model of Emotional Intelligence. E-Journal of Applied Psychology, 5(2), 25-31. https://doi.org/10.7790/ejap.v5i2.175

Morgan, D. L. (2014). Integrating qualitative and quantitative methods: A pragmatic approach. Los Angeles, CA: Sage.

Najafi, M., Motaghi, Z., Nasrabadi, H. B., \& Heshi, K. N. (2016). "Debate” learning method and its implications for the formal education system. Educational Research and Reviews, 11(6), 211-218. https://doi.org/ 10.5897/ERR2015.2316

Omelicheva, M. (2006). Global Politics on Trial: Using Educational Debate for Teaching Controversies of World Affairs. International Studies Perspectives, 7(2), 172-186. https://doi.org/10.1111/j.1528-3585.2006.00238.x

Panapto. (2019). 7 Unique Flipped Classroom Models - Which is Right for You? Retrieved from https://www.panopto.com/blog/7-unique-flipped-classroom-models-right/

PsychTest. (n./d.). Multiple Intelligences \& Learning Style Test. Retrieved from https://testyourself.psychtests.com/testid/3103

Sagenmüller, I. (2020). 6 types of flipped classroom to innovate in higher education. U-Planner. Retrieved from https://www.u-planner.com/en-us/blog/flipped-classroom-six-types

Scholastic. (2005). Checklist: Learning Activities That Connect with Multiple Intelligences. Retrieved from 
https://www.scholastic.com/teachers/articles/teaching-content/clip-save-checklist-learning-activities-connect-m ultiple-intelligences/

Schoonenboom, J., \& Johnson, R. B. (2017). How to Construct a Mixed Methods Research Design. Kolner Zeitschrift fur Soziologie und Sozialpsychologie, $\quad 69$ (Suppl 2$), \quad 107-131$. https://doi.org/10.1007/s11577-017-0454-1

Toner, P. \& Woolley, R. (2016). Perspectives and debates on vocational education and training, skills and the prospects for innovation. Revista Española de Sociología, 25(3), 319-342. http://dx.doi.org/10.22325/fes/res.25.3.2016.319

University of Waterloo. (n./d.). Course design: planning a flipped class. Retrieved from https://uwaterloo.ca/centre-for-teaching-excellence/teaching-resources/teaching-tips/planning-courses-and-assig nments/course-design/course-design-planning-flipped-class

Williams-Brown, Z. \& Wilson, M. (2016). The complexity of in-class debates in Higher Education: student perspectives on differing designs. Educational futures, 7, 14-28.

Williams-Brown, Z. (2015). The use of in-class debates as a teaching strategy in increasing students' critical thinking and collaborative learning skills in higher education. Educational futures, 7, 39-55.

Winarti, A., Yuanita, L., \& Nur, M. (2019). The effectiveness of multiple intelligences-based teaching strategy in enhancing the multiple intelligences and science process skills of junior High School students. Journal of Technology and Science Education, 9(2), 122-135. https://doi.org/10.3926/jotse.404

Yarema, A. E. (2002). A Decade of Debate: Improving Content and Interest in History Education. The History Teacher, 35(3), 389-398. https://doi.org/10.2307/3054444

Zare, P., \& Othman, M. (2013). Classroom debate as a systematic teaching/learning approach. World Applied Sciences Journal, 28, 1506-1513. https://doi.org/10.5829/idosi.wasj.2013.28.11.1809

\section{Appendices}

Appendix 1. Lesson Plan Example

Course title: "The USA policy and Integration Processes in Europe in the post-bipolar era".

Lesson Topic: Democracy

Type of the class: Round-table discussion

Teacher's role: moderator/facilitator

Objectives:

- $\quad$ to improve students' argumentative, counter-argumentative and reasoning skills;

- $\quad$ to practice students' presentation skills;

- $\quad$ to practice note-taking skills;

- $\quad$ to reach mutual understanding of what democracy is and what specific about the democracies in the USA and Europe is;

Expected outcomes:

- $\quad$ students' awareness of deferent perspectives on democracy as a phenomenon;

- $\quad$ students' ability to express and justify their opinion using appropriate functional language;

- $\quad$ students' ability to use several note-taking techniques like outlining, bulleting, "boxing method", charting and mind-mapping.

Prerequisite (prior the class) reading:

Diyarbakirlioglu, K. (2019). Russian and European Union's Quest for the formation of a European security system after the cold war. Cogent Social Sciences, 5(1), 1683928. https://doi.org/10.1080/23311886.2019.1683928

Gorodnia, N. (2018). Transformation of the post-Cold War International System: Trends and Prospects. Retrieved from https://www.researchgate.net/publication/325248874_Transformation_of_the_post-Cold_War_International_Sy 
stem_Trends and Prospects

Kandyuk, O. (2016). Transatlantic Relations in Post-Bipolar Era: Strategy for a "New Europe". Eastern Review, 5, 39-50. https://doi.org/10.18778/1427-9657.05.04

Voskopoulos, G. (Ed.). (2007). Transatlantic Relations and European Integration - Realities and Dilemmas. Hyderabad: ICFAI University Press.

\section{LESSON PLAN}

\begin{tabular}{|c|c|c|}
\hline Segment/Activity & Presentation or tactics of engagement of students & Time \\
\hline Lead-in & $\begin{array}{l}\text { Group discussion: A teacher starts it by moderating the discussion of a question: "What } \\
\text { is democracy?" } \\
\text { Follow up questions: } \\
\text { Is democracy related to legal or social dimension? } \\
\text { Why, do you think, people have been striving for the democracy for centuries? }\end{array}$ & $10 \min$ \\
\hline Eliciting & $\begin{array}{l}\text { The Ss, mingled in pairs, are distributed the handouts with headings written on them: } \\
\text { "Democracy in Learning", "Democracy in Governance" and "Democracy in } \\
\text { International context". There are assigned to work out together and write a definition of } \\
\text { 'democracy' in relation to suggested context. Having finished, they were supposed to } \\
\text { pass their handout to the next pair who were to do the same. Concurrently, they received } \\
\text { the handout from the other pair and were expected to write the definition for } \\
\text { 'democracy' under a different heading. }\end{array}$ & $10 \min$ \\
\hline Commenting & $\begin{array}{l}\text { When everybody has finished, each pair read the definitions they most agree with and } \\
\text { comment them on. }\end{array}$ & $5 \min$ \\
\hline $\begin{array}{l}\text { Revising the } \\
\text { signposting } \\
\text { language }\end{array}$ & Ss do the quick quiz to revise the signposting language. & $5 \mathrm{~min}$ \\
\hline $\begin{array}{l}\text { Quotes; Ss' } \\
\text { Presentation of } \\
\text { their views of } \\
\text { quotes }\end{array}$ & $\begin{array}{l}\text { The teacher places the quotes on the floor in a circle and suggests Ss to walk around for } \\
2 \text { min to find and decide on the one which appeals them most. When the T lets them } \\
\text { know, they pick up the quote they like and prepare a half-a-minute presentation of the } \\
\text { one to deliver to the class or to the other student. } \\
\text { Having done this, the Ss get ready with the presentations of the quotes they have chosen } \\
\text { and deliver them to either the class or to a partner. }\end{array}$ & $30 \mathrm{~min}$ \\
\hline $\begin{array}{l}\text { Philosophical } \\
\text { Chairs Debate }\end{array}$ & $\begin{array}{l}\text { The area for the debate is set up. Two chairs labelled "FOR" and "AGAINST" are put in } \\
\text { front of the class and motions are projected on the screen or written on A4-sheet of } \\
\text { paper and stuck to the white board. } \\
\text { Motion 1: America dominates the economic relations with the EU. } \\
\text { Motion 2: The EU security is challenged by the USA. } \\
\text { Motion 3: The prospects for the USA-EU relations are blur. } \\
\text { Ss take a seat on the either "FOR" chair or "AGAIST" chair to express themselves. The } \\
\text { others listen, ask follow up questions or take a different chair to express the opposing } \\
\text { view. } \\
\text { The teacher uses the Debate Assessment Chart to provide feedback on the Ss' answers. }\end{array}$ & $20 \mathrm{~min}$ \\
\hline Wrap-up & $\begin{array}{l}\text { The teacher summarizes and provides the comments on the students' ideas and } \\
\text { performance. }\end{array}$ & $5 \mathrm{~min}$ \\
\hline Assignment & ack to one of the peer's answers in the debate. & \\
\hline
\end{tabular}

